\title{
PATterns OF CRIME DURING THE COVID-19 PANDEMIC IN BELGIUM
}

Wim Hardyns ${ }^{1,2}$, Janneke M. Schokkenbroek ${ }^{1,3}$, Evelyn Schapansky ${ }^{1}$, Ines Keygnaert ${ }^{4}$, Koen Ponnet ${ }^{3}$, $\&$ Christophe Vandeviver ${ }^{1,5}$

${ }^{1}$ Institute for International Research on Criminal Policy (IRCP), Department of Criminology, Criminal Law, and Social Law, Ghent University, Ghent, Belgium.

${ }^{2}$ Faculty of Social Sciences, University of Antwerp, Antwerp, Belgium.

${ }^{3}$ IMEC-mict, Department of Communication Sciences, Ghent University, Ghent, Belgium.

${ }^{4}$ International Centre for Reproductive Health (ICRH), Department of Public Health and Primary Care, Ghent University, Ghent, Belgium.

${ }^{5}$ Research Foundation-Flanders (FWO), Brussels, Belgium.

Direct correspondence to: Christophe Vandeviver, Department of Criminology, Criminal Law and Social Law, Ghent University, Universiteitstraat 4, 9000 Ghent, Belgium.

Email: Christophe.Vandeviver@UGent.be

Declaration of interest: None.

Funding statement: The work of Wim Hardyns and Koen Ponnet is supported in part by the Research Foundation - Flanders (FWO) Fundamental Research Projects funding scheme under Grant G010519N. The work of Janneke M. Schokkenbroek is supported by the FWO PhD Fellowship fundamental research funding scheme under Grant $11 \mathrm{~K} 5421 \mathrm{~N}$. The work of Christophe Vandeviver is supported in part by the FWO Postdoctoral Fellowship funding scheme under Grants 12C0616N and $12 \mathrm{C} 0619 \mathrm{~N}$.

Acknowledgments: We wish to thank the Belgian Federal Police, particularly the Department of Police Information and IT Resources, for providing us with the crime statistics for the years 2015-

2020. Also, we wish to thank our colleagues Sarah Anrijs, Joke Depraetere, Sabine De Moor, Lotte De Schrijver \& Anne Nobels for the collaboration in the research projects and for their efforts in gathering data on domestic violence during the COVID-19 pandemic.

\section{QUICK MENU:}

$\underline{\text { INTRODUCTION }}$

METHODS

RESULTS

DISCUSSION

CONCLUSION

REFERENCES

TABLES

FIGURES

APPENDIX 


\section{PATTERNS OF CRIME DURING THE COVID-19 PANDEMIC IN BELGIUM}

\section{INTRODUCTION}

In an effort to contain the spread of COVID-19, Belgian governments have enforced constraints on social life such as social distancing, prohibiting social gatherings, school closures, and enforced stay-athome orders - colloquially referred to as "the lockdown". Such public health measures, in particular stay-at-home orders, can have unintended adverse consequences for crime (Ashby 2020; Eisner \& Nivette 2020). Criminologists argue that the public health measures associated with COVID-19 affect the causal mechanisms of crime in a variety of ways, such as changes in routine activities, (dis)appearance of crime opportunity structures, changes in levels of formal and informal social control, and increased stress and anxiety. Therefore, crime scholars anticipated that lockdowns might differentially affect crime types, with certain crimes decreasing (e.g., theft and property crime) and others increasing (e.g., cybercrime). Indeed, in Belgium, already in the beginning of the lockdown police saw crime rates drop by $30 \%$ (Nieuwsblad 2020).

It is particularly argued that the lockdown has created the perfect storm for domestic violence to increase (Eisner \& Nivette 2020; Vandeviver et al. 2020). Not only are lockdown measures associated with elevated violence-inducing emotions and psychological states such as stress and anxiety (Brooks et al. 2020; Eisner \& Nivette 2020) and maladaptive coping strategies (Gillespie et al. 2021), they also confine victims and offenders together to their homes and deprive victims from opportunities to escape violent households to seek much needed care (Piquero et al. 2021). Early on in the COVID-19 epidemic in Belgium, multiple online emergency services delivered evidence of increases in domestic violence (e.g., Verplancke \& Keygnaert 2020) which was later confirmed by a number of self-report surveys (e.g., Schokkenbroek et al. 2021; Keygnaert et al. 2021; Vandeviver et al. 2020).

In this chapter, we describe the development of the COVID-19 pandemic and its relation with different crime patterns in Belgium. Through a thorough description of (1) governmental measures taken to contain and decrease the spread of coronavirus and (2) crime statistics from 2020 in light of these measures and compared to statistics from previous years, we identify patterns of crime related to the COVID-19 pandemic. Additionally (3), we pay extra attention to the case of domestic violence during the pandemic in Belgium by describing and discussing data from secondary sources as well as from our own empirical survey studies.

\section{DEVELOPMENT OF THE COVID-19 PANDEMIC IN BELGIUM}

On January 28, the newly built website www.info-coronavirus.be informed about the new coronavirus in Wuhan, China. The travel advice for China was adjusted to discourage non-essential travel but it was highlighted that there was no reason for concern. Five days later, on February 2, nine Belgian citizens were repatriated from China. Upon return, one of those travellers soon developed symptoms of COVID19 (Info-Coronavirus 2020).

In the following, we provide a timeline of the development of the COVID-19 pandemic in Belgium for the year 2020. This timeline provides an overview of significant dates during this pandemic, significant measures that were taken to limit the spread of the new coronavirus, and relaxations of these measures.

Figure 1 combines these dates with the rates of cases, patients in intensive care, and deaths per day. The second peak of new cases is to be interpreted with caution as this curve highly depends on the number of tests performed. In the second wave, starting in October 2020, more tests were conducted than in the first wave, during March or April 2020. For example, about 11,000 tests were performed daily on average in April. In October, the daily average was 56,000 tests (Ritchie et al. 2020). The positivity rate of all performed tests in those two months was similar (18\% and $16 \%$, respectively). 


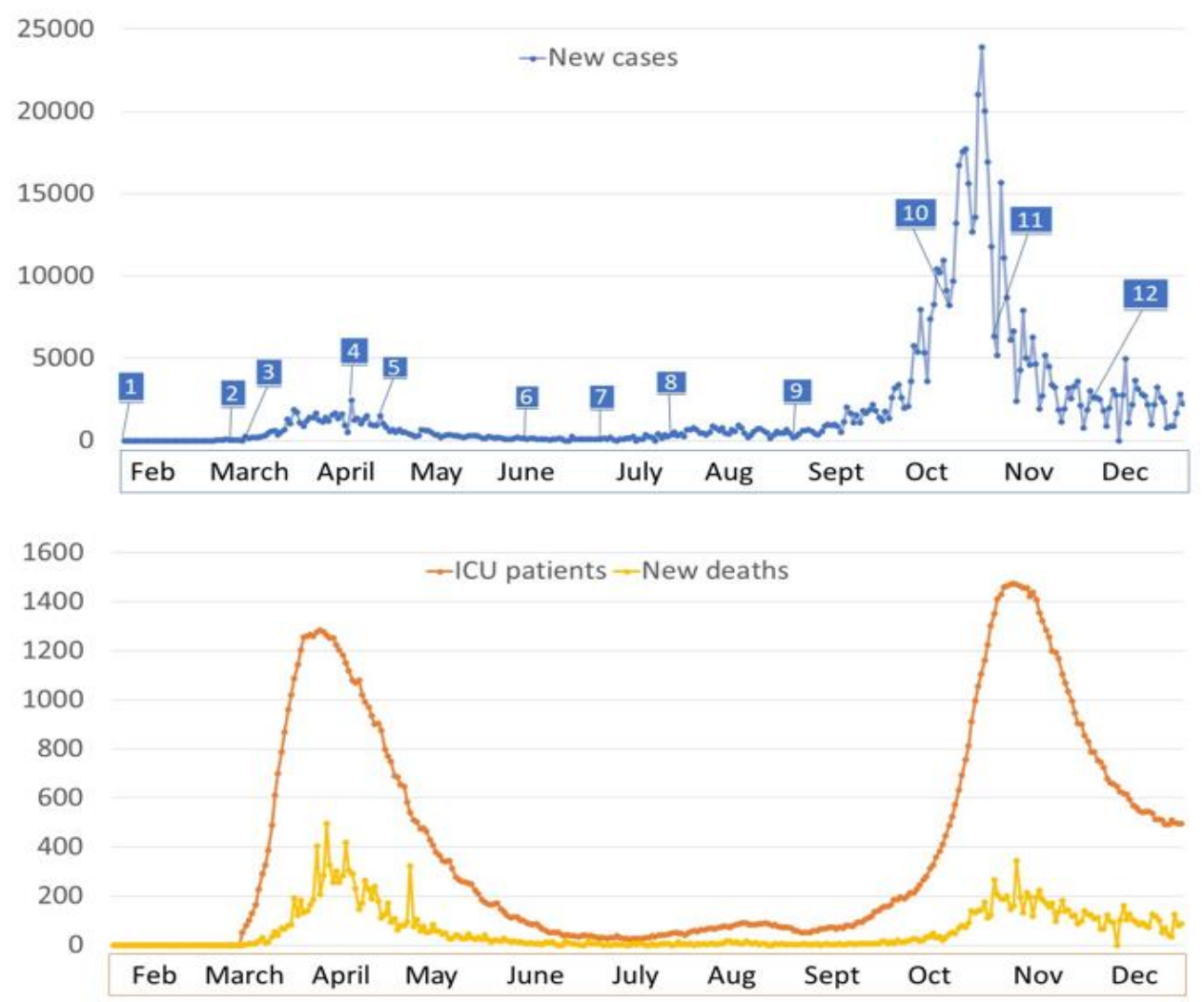

Figure 1. Rates of COVID-19 cases, deaths and patients in intensive care units. Data source: ourworldindata.org/coronavirus

We further put these dates into context with reports from the Belgian institute for health, Sciensano, who monitored the acceptance of and compliance with the measures in the Belgian population.

1. The first case of COVID-19 in Belgium was confirmed on February 4, 2020. It took until March 1 for the second case to be confirmed. From that day, confirmed cases would rise drastically until, only two weeks later, Belgium reaches one thousand COVID-19 cases (Ritchie et al. 2020).

2. On March 10, the first death related to COVID-19 was confirmed. On the same day, the National Security Council convened for the first time and announced that the evolution of the spread of the coronavirus will be evaluated on a daily basis and that measures will be taken to limit its spread (Info-Coronavirus 2020). During this first meeting, it was decided that large events of more than 1000 people would be cancelled until the end of March. Employees were asked to work as much as possible from home and schools were advised to cancel school trips (D'hoore 2020).

3. On March 12, the National Security Council convened again and decided further measures. The first Belgian lockdown would start on March 18. The measures included the following:

a. Everyone was asked to stay as much as possible at home. It was allowed to leave the house for essential reasons and sports activities with one other persons or people from the same household;

b. Primary and secondary schools closed, universities were encouraged to develop procedures for remote teachings;

c. Sports and cultural activities were cancelled and prohibited ;

d. Bars, restaurants and non-essential stores had to close;

e. Non-essential international travel was forbidden, border controls were implemented. 
In their first survey, conducted in the first week of April, Sciensano found that participants felt generally well informed about COVID-19 and the current measures (Demarest et al. 2020a). However, the measures to keep distance, follow hygiene rules, and stay at home were not strictly followed by the population. The main reasons for non-compliance were not belonging to a risk group, having to continue economic activities and the feeling that a contraction of the virus could simply be avoided by being careful or alone. Young people felt less well informed and were less likely to strictly comply with the measures.

4. On April 15, 2454 new cases were confirmed in one day (211/million). This was, at that time, the highest number of new confirmed cases in a single day. However, the real number was likely much higher due to limited testing. At that time, 4440 people had died (Ritchie et al. 2020).

In the third week of April, Sciensano conducted a second survey (Drieskens et al. 2020) to monitor acceptance of the measures in the Belgian population. As in the first survey, the population indicated that they were sufficiently informed about COVID-19 and the current measures. Compliance with the measures decreased slightly compared to the previous report. Especially men, young people and people with little confidence in institutions were less likely to strictly comply with the measures.

5. An 'exit strategy' was announced on April 24:

a. the first phase would start on May 4: Fabric stores could open so that people could make their own face masks. Non-urgent consultations with doctors and in hospitals would be possible again and outdoor activities would now be allowed with two other people (instead of only one other person). The daily number of new cases was down to 361 (Ritchie et al. 2020). One week later, all stores could open again under certain regulations, such as limited number of clients (Info-Coronavirus 2020).

b. May 10: One household could invite up to four other people, given that those did not meet others (Info-Coronavirus 2020). New daily cases were rising again at that time but decreased soon after (Ritchie et al. 2020).

c. May 18: Among other relaxations, primary and secondary schools could re-open. All large events were cancelled until June 30 (Info-Coronavirus 2020).

Based on their third survey (Demarest et al. 2020b), Sciensano reported that the Belgian population indicated again that they were sufficiently informed about COVID-19 and the measures in place. People felt less informed than previously about the relaxation of restrictions and quarantine measures as well as travel recommendations. The percentage of people indicating that they did not strictly adhere to the measures increased further. Young people, men, and people with a low level of health literacy were relatively more likely to indicate that they did not strictly follow the measures.

6. On June 8, the probably most significant step towards a 'normal' public life was taken: Bars, cafés and restaurants re-opened. Up to 10 people were allowed to sit together, staff had to wear masks (Info-Coronavirus 2020). One could meet up to 10 different people per week. Companies could resume their activities, but working from home was still recommended, and travelling within Belgium was allowed (HLN 2021). The 7-day average of new cases was 117 at this time (Ritchie et al. 2020). On June 15, Belgium re-opened its borders (Info-Coronavirus 2020).

7. On July 1, the final phase of the exit strategy began: most public spaces could re-open, such as wellness centres, cinemas and theatres. Night clubs and large events could not resume their activities. The 'social bubble' is extended to 15 people per week. Indoor events could take place with up to 200 and outdoor events with up to 400 people (Info-Coronavirus 2020). 
8. July 25: Over the past two weeks, the rate of new cases had increased again (Info-Coronavirus 2020). Instead of transitioning into further relaxations, masks were now mandatory in crowded public places and for guests of the catering industry. The social bubble was reduced to five people and a passenger locator form was introduced for persons who were outside of Belgium for more than 48 hours to track their movements and identify high-risk contacts. On July 28, the province of Antwerp became a high-risk area and introduced a curfew and other restrictions. The measures in the entire country became stricter (HLN 2021).

9. On September 1, the measures were relaxed again. The school year started with the only measure being mandatory masks for students older than 12 and teachers (HLN 2021). The number of new daily cases started rising again soon after (Info-Coronavirus 2020). Six weeks later, the measures were further tightened: Only three contacts outside one's household, indoors and outdoors, were allowed. Bars had to close at 11PM and could only allow four people at one table. Working from home office was strongly recommended again (InfoCoronavirus 2020).

At the end of September, the Belgian population still felt sufficiently informed about COVID 19 measures (Braekman et al. 2020). However, the percentage of people indicating that they were sufficiently aware of current government measures had again decreased. Compliance with the measures regarding hygiene and distancing decreased further. In comparison with the third survey, more people indicated not to stay at home in case of illness. On the other hand, more people strictly used face masks in places where the distance of 1.5 metres could not be respected. Young people and men were again less likely to strictly adhere to the measures (Braekman et al. 2020).

10. On October 19, bars and restaurants had to close fully for at least four weeks. A curfew from midnight until 5AM was introduced and alcoholic beverages could not be sold after 8PM. Only one close contact was allowed (Info-Coronavirus 2020).

11. On November 2, working from home was mandatory when the activities allowed for it. Indoor activities (e.g., sauna and cinemas) were cancelled and cultural places, except for libraries, had to close again. Non-essential stores could only remain open for pick-ups and delivery. Nonmedical services with close contact (e.g., hair salons) closed. All educational institutes switched to maximum online lessons (Info-Coronavirus 2020).

12. On December 1, non-essential stores re-opened for a limited number of customers and under strict hygiene requirements (Info-Coronavirus 2020).

In the last survey of 2020 (Berete et al. 2020), conducted in the second week of December, more people felt adequately informed about current government measures than in June and September. More people than in September indicated that they strictly followed the measures. The least observed measure was to limit close contacts to one person. The measure with the highest rate of compliance was the use of face masks where required. Again, young people and men were relatively more likely to indicate that they did not strictly comply with the measures.

All in all, it can be concluded that the acceptance of and compliance with the measures to limit the spread of the coronavirus decreased over time. However, it increased again in the period from October to December 2020, but especially the restrictions of close contacts were less accepted (Berete et al. 2020). The measures limiting the amount of people one was allowed to meet with or visit were probably the ones that led most to confusion and discussion in the public debate (e.g., Grommen 2020). Based on the overview of measures taken by the government, it becomes clear that these changed fairly often. The so-called social bubble was reduced to one or extended to up to 15 people based on the current rates of new cases. This rule mostly applied to contacts over one week which could then change in the next week 
(HLN 2021). That this rule was difficult to follow and to control may have led to less acceptance and compliance.

Unlike in other European countries, there were few major protests against the coronavirus measures in Belgium. In September 2020, 4000 people came together in Brussels, under compliance with the measures in place, to protest for better pay and conditions in the health care sector (HLN 2020b). Several smaller 'silent protests' were held to protest for better financial support of those working in the cultural sector (e.g., De Morgen 2020).

\section{PATTERNS OF CRIME DURING THE COVID-19 PANDEMIC IN BELGIUM}

As governmental (lockdown) measures have drastically impacted people's daily lives and routines, it can be expected that this impact can also be observed with regard to crime rates. Indeed, already two weeks after the first lockdown measures were instated in March 2020, the Belgian police observed an overall drop in crime rates of approximately 30\% (HLN 2020a). Based on crime statistics from 2015 to 2020 from the Federal Police (2020), the monthly crime rates of 2020 compared to those of 2015-2019 are presented for a broad variation of crime types in Figure 2. Due to data availability, the analyses of crime rates for 2020 are limited to the period January to September 2020.

As can be seen in the figure, crime rates for most types of crime dropped within the first weeks of the pandemic lockdown. More specifically, crime rates decreased considerably during the pandemic lockdown compared to average crime rates from the same period in previous years (2015-2019) and compared to absolute crime rates from 2019 for the following crime types: burglary (-37\% compared to average $2015-2019,-26 \%$ compared to 2019), violence in public spaces (-18\% compared to average 2015-2019, $-17 \%$ compared to 2019), vehicle theft (-29\% compared to average $2015-2019,-22 \%$ compared to 2019) and theft (-31\% compared to average 2015-2019, -30\% compared to 2019). For domestic violence, reported crime rates during the pandemic lockdown were relatively similar compared to previous years (-2.7\% compared to average $2015-2019,-3.7 \%$ compared to 2019$)$. It should be noted that police statistics on domestic violence, however, only reflect a small part of its occurrence due to substantial victim underreporting. Given that most crime rates for the months January and February 2020 were relatively similar to crime rates of previous years for the same period, the impact of the COVID-19 pandemic and lockdown measures on reported crime rates is tangible.

For most crime types, an increase can be observed once lockdown measures were relaxed later on in June 2020. These increased crime rates in the summer of 2020 do not closely resemble the (average) crime rates of previous years, however, with the exception of rates of domestic violence. The number of reported domestic violence incidents in August 2020 actually exceeded that of any other month in the past five years. We discuss domestic violence in detail in the third part of this chapter. 

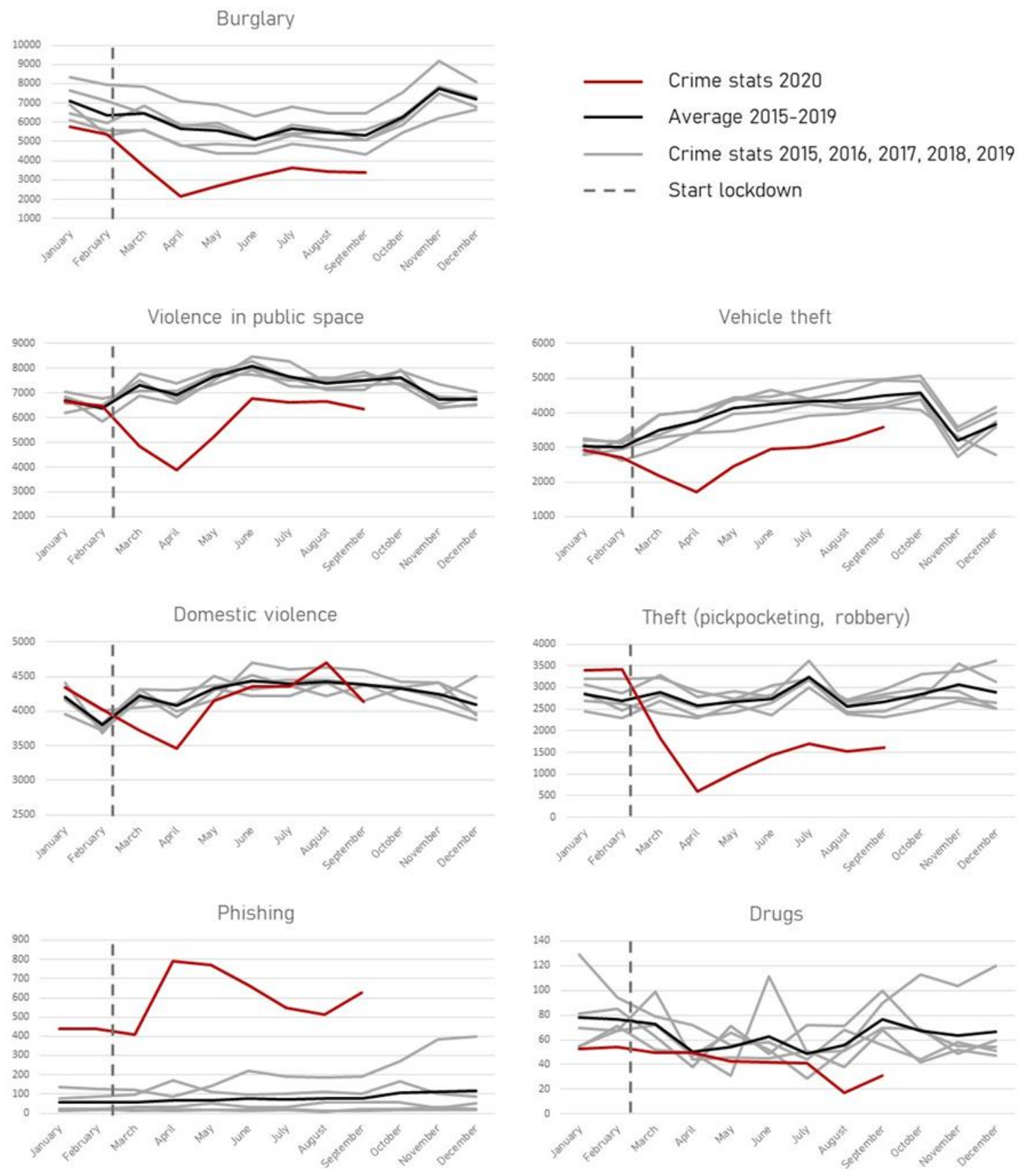

Figure 2. Crime statistics in Belgium from 2015 to September 2020.

Compared to the crime types just described, two crime types that are presented in Figure 2 follow a different crime pattern, namely, cybercrime - specifically phishing, and drug-related crime. Firstly, quite possibly, the restricted opportunities for physical crimes may have resulted in a displacement of criminal activity from the physical to the online environment (Buil-Gil et al. 2021). Indeed, while offline and face-to-face types of crime decreased during the pandemic, cybercrime took a giant leap. As can be seen in Figure 2, this was particularly the case for phishing (+766\% compared to average $2015-2019,+270 \%$ compared to 2019), a type of online scam where criminals send fraudulent online messages, often impersonating a legitimate organization, with the purpose of cheating people out of their money (Lastdrager 2014). In addition to these official police statistics, the Centre for Cybersecurity in Belgium (CCB) received 2.8 million reports of cybercrime , 1.0 million more than a year before in 2019 (Van 
Hoorenbeek \& Verberckmoes 2020). Whereas the displacement of crime from physical to online environments is already a testament to criminals' flexibility and willingness to adapt to societal developments, this is further demonstrated by the nature of their phishing attacks. According to the CCB, cybercriminals aptly responded to the COVID-19 pandemic by spreading phishing attacks with pandemic-related content, such as fake sales of mouth masks and vaccine offers (Van Hoorenbeek \& Verberckmoes 2020). People consumed large amounts of media during the lockdown to stay up to date about COVID-19 pandemic developments (Casero-Ripollés 2020) or to seek entertainment by means of a coping mechanism (Cauberghe et al. 2021). Because of this, both the number of suitable victims as well as the likelihood for internet users to be victimized increased.

Secondly, drug-related crime statistics as presented in Figure 2 specifically concern offenses related to the production and import/export of synthetic drugs and cannabis. As can be seen in the figure, the amount of drug-related offenses during the pandemic lockdown strongly fluctuates from month to month. Overall, drug-related offenses strongly decreased during the pandemic lockdown ( $-44 \%$ compared to average 2015-2019, -48\% compared to 2019). However, when we look at the two types of drugs separately, different patterns emerge. Whereas the production and distribution of synthetic drugs severely decreased in 2020 (-41\% compared to average $2015-2019,-52 \%$ compared to 2019$)$, this is to a much lesser extent the case for cannabis (-20\% compared to average 2015-2019, -17\% compared to 2019). Notably, crime rates for cannabis production and distribution were in fact higher in the month May in 2020 compared to May 2019 ( $+29 \%)$. A possible explanation for these differences in production and distribution rates of cannabis and synthetic drugs can be found in people's drug consumption behaviours. Indeed, in a cause-effect fashion, similar fluctuations were found in patterns of drug use during the COVID-19 pandemic lockdown in Belgium. In a large-scale survey study conducted by Sciensano (2021), it was found that the consumption of marihuana and ecstasy (strongly) increased during the first lockdown in Belgium, whereas the consumption of powdered cocaine and amphetamines strongly decreased compared to the period before. It is possible that the consumption of most synthetic drugs strongly decreased during the pandemic lockdown due to nightlife being shut down. At the same time, people spend more time at home and may have felt a stronger need to relax and alleviate anxiety during the stressful time of the pandemic lockdown, increasing cannabis consumption.

Additionally, while we observed a displacement from physical to online environments in theft crimes, it was found that the online purchase of drugs did not significantly increase during the lockdown, with most respondents citing regular dealers as the most important provider during the pandemic (Sciensano 2021). Interestingly, a strong increase was found in the amount of people that grew their own marihuana within the first six months of the COVID-19 pandemic, possibly to become less dependent on the market for personal drug use.

\section{Non-Compliance with COVID-19 Measures}

Another type of offense that is of particular interest during the pandemic concerns the non-compliance with governmental COVID-19 measures, which was punishable by law according to article 187 of the Act of 15 May 2007 concerning civil security. Violations of COVID-19 measures varied in nature and severity. Examples are not wearing a mask in an area in which this is mandatory, gathering in large groups or organizing illegal parties, violating the midnight curfew, or non-compliance with health regulations on an organizational level. Police records on such offenses may paint an additional picture of whether or not people were inclined to adhere to COVID-19 measures in Belgium. From January to September 2020, Belgian police officers recorded a total of 130.612 violations, which were categorized as violations in opposition to public health. Unsurprisingly, this number is tremendously higher than the 817 acts in defiance of public health recorded in 2019. Violations of COVID-19 measures by an individual person could be sanctioned with a fine ranging from $€ 209$,- to $€ 4000$,- and/or imprisonment 
from 8 days to 3 months, depending on the nature and severity of the violation. For organizations, possible sanctions vary more greatly, as violations may also concern violations of general safety obligations and employee well-being regulations. It should be considered, however, that violation of measures may have been the result of confusion or lack of knowledge about which measures were in effect at a given moment due to vast changes herein.

\section{DOMESTIC VIOLENCE DURING THE COVID-19 PANDEMIC}

In addition to the general overview of crime levels in Belgium in 2020, we particularly focus on the case of domestic violence during the COVID-19 pandemic. Domestic violence concerns violent and abusive behaviours that take place within the domestic sphere. Within the criminal justice system in Belgium, a distinction is made between types of physical, sexual, psychological, and economic domestic violence, and victims are categorized as partner, child, or other family member. Figure 3 provides an overview of all domestic violence incidents in 2020 that were reported to the police compared to 2015-2019 with partners, children, and other family members as victims.

Whereas many types of criminal behaviours (strongly) decreased due to the COVID-19 pandemic and the governmental lockdown measures, no strong decreases were observed with regard to domestic violence. With the exception of the first months of the pandemic lockdown, crime statistics from the Belgian criminal justice system suggest that, for the most part of 2020, the number of people reporting domestic violence to the police remained relatively similar compared to a year before (-3.7\%). As almost all of the other types of crime decreased in 2020 and already displayed such a decreasing trend over the past five years, the finding that this is not the case for domestic violence incidences is in itself a worrisome observation.

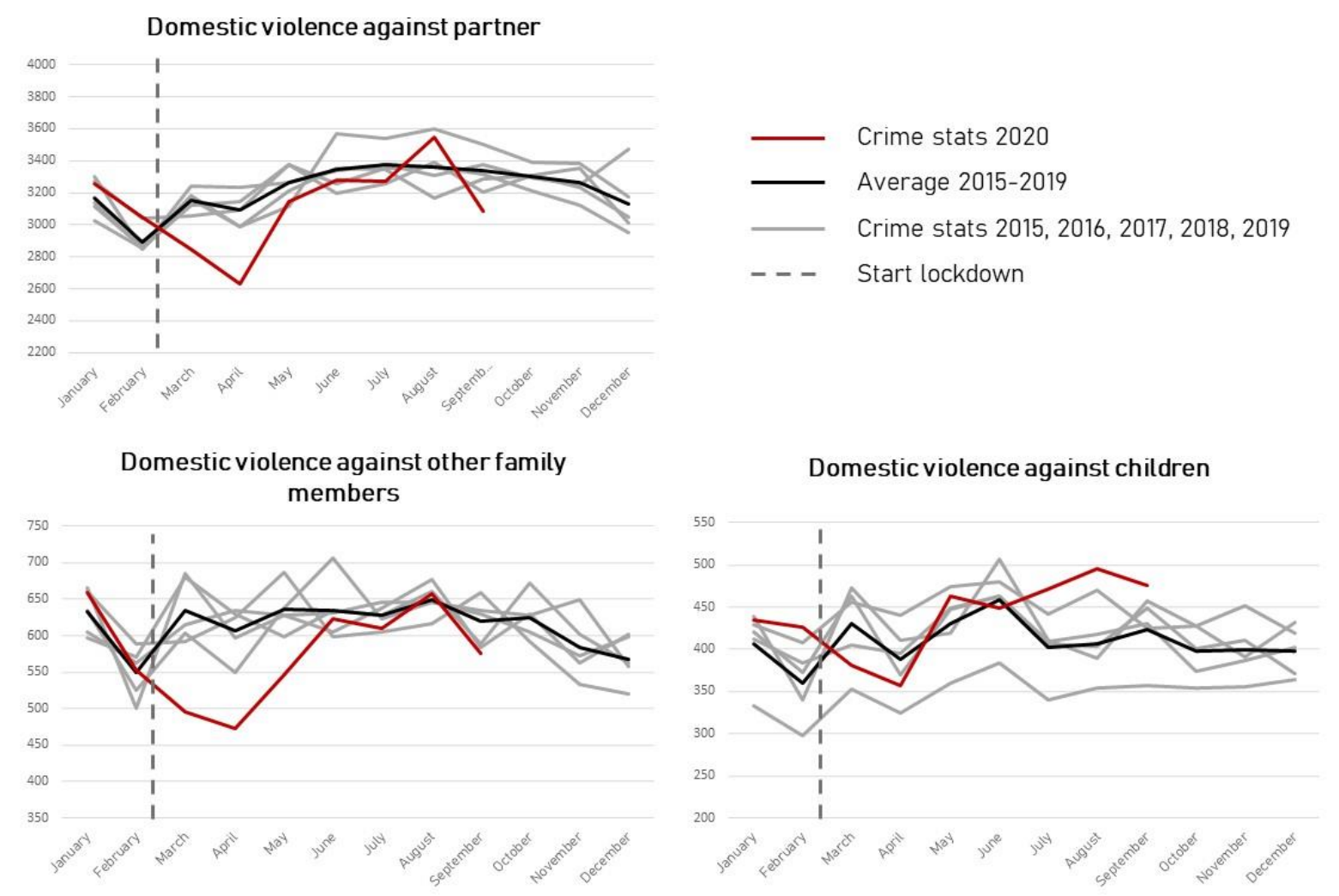

Figure 3. Domestic violence rates in Belgium from 2015 to September 2020.

Police statistics on domestic violence generally reflect only a small part of the problem. Most cases of domestic violence are not reported, and studies consistently show that prevalence rates of domestic 
violence acquired from self-report surveys are much higher compared to reported cases in criminal justice systems (e.g., Gracia 2004). This "iceberg" of domestic violence prevalence is particularly important to acknowledge when considering domestic violence incidences in the context of the COVID19 pandemic. Lockdown measures urging people to stay inside and to practice 'social distancing' may have increased domestic violence prevalence and severity due to increased (social) isolation and stressors. Indeed, several studies have found evidence for the impact of pandemic-related lockdown measures and stressors on domestic violence frequency and severity (e.g., Lyons \& Brewer 2021; Cannon et al. 2021). At the same time, the COVID-19 pandemic and governmental lockdown measures created additional barriers for victims of domestic violence to seek help, such as concerns about retaliations by their partner or parent, lack of social support due to the social isolation, and safety concerns about coronavirus infection (e.g., Boxall et al. 2020). Due to this tangible impact of the COVID-19 pandemic, several scholars have described domestic violence during the coronacrisis as "a pandemic within a pandemic" (e.g., Evans et al. 2020). Yet, in Belgium during the lockdown, police extensively controlled for non-necessary displacements so seeking for help without having to denounce it to the police became difficult (Keygnaert et al. 2021).

To comprehensively illustrate the impact of the COVID-19 pandemic on domestic violence in Belgium, we consulted additional sources, such as victim helplines and data from our own empirical research, in addition to police statistics.

\section{Domestic Violence in Belgium During the Pandemic Lockdown}

Already in April 2020, within weeks after the start of the lockdown, the 1712 helpline, a helpline aimed to provide support to victims of violence and abuse, reported that the number of calls had more than doubled compared to the same period a year before (Hulplijn 1712 2020). In total, 952 calls were made concerning a total of 1269 (potential) victims, most calls concerned child abuse and partner violence. For partner violence alone, the number of calls (331) in April 2020 had tripled compared to the monthly average of 2019 (Hulplijn 1712 2020). In addition to reports from the 1712 helpline, numbers from the Ch@tline sexual violence (Verplancke \& Keygnaert 2020) further indicate the impact of the COVID19 pandemic and the lockdown measures. Between March 2020 and May 2021, an average of 152 calls per month were made to this helpline dedicated to support victims of sexual violence. In comparison, an average of 85 calls per month were made between September 2019 and February 2020. Thus, during the pandemic, the number of calls increased by $79 \%$.

These numbers from Helpline 1712 and Ch@tline sexual violence illustrate that domestic violence was a prevalent problem during the COVID-19 pandemic in 2020. To further increase our understanding of the impact of the pandemic and lockdown measures on domestic violence in Belgium, we conducted two independent but complementary large-scale survey studies (Hardyns et al. 2020). In both studies, the survey was administered online and distributed through various online channels such as social media accounts and departmental websites. Study $1(n=2889$; Ponnet et al. 2020) was conducted from April 3rd to April 17th, 2020, approximately three weeks after the first lockdown measures were instated. Study 2 ( $\mathrm{n}=4047$; Keygnaert et al. 2020) was conducted from April 13th to April 27th, 2020.

\section{Study 1: Verbal partner violence}

Study 1 specifically focused on verbal violence between romantic partners. In total, 1491 of the respondents (76.3\% women) of study 1 lived together with their partner during the lockdown. We asked respondents to report on how often they had experienced verbal and physical altercations with their partner during the lockdown. Of the 1491 people, 36 (1.7\%) had experienced physical partner violence rarely to very often during the pandemic lockdown (Schokkenbroek et al. 2020). Five of these people were men and 31 were women. Our results showed that men and women did not significantly differ in 
how frequently they experienced physical violence with their partner, nor did people from different age groups.

Verbal altercations were much more common during the pandemic lockdown. In total, 1096 (73.5\%) people reported that they had rarely to very often experienced verbal aggression with their partner during the lockdown (Schokkenbroek et al., 2021). We additionally examined which groups of people in particular experienced verbal partner violence. Our findings showed that women, younger people (aged 18-35 years), students, people whose partner was long-term unemployed or (temporarily) unemployed due to the COVID-19 pandemic, parents of children younger than 18 years, people without the ability to seclude themselves from other members of the household, and people with less social contacts with whom they could share personal stuff experienced more verbal partner violence during the COVID-19 pandemic.

In addition to this, we examined if feelings of stress about the COVID-19 pandemic and about potential coronavirus infection were related to people's verbal partner violence experiences. We found that higher levels of stress about the pandemic itself and lower levels of stress about potential coronavirus infection were related to more partner violence experiences during the pandemic lockdown (Schokkenbroek et al. 2021). Whereas one would expect that feelings of stress and fear place strain on people's relationships and may result in conflicts between partners, it is surprising that the opposite was found to be the case for fear of coronavirus infection. A possible explanation could be that an apparent more careless perspective on the pandemic and potential coronavirus infection by one of the partners may in fact be the subject of couples' conflicts, but for now this we can only speculate on this.

\section{Study 2: Psychological, physical, and sexual domestic violence}

Whereas study 1 particularly focused on verbal violence between partners, study 2 examined people's experiences of psychological, physical, and sexual domestic violence during the pandemic lockdown. For each type of violence, we asked respondents $(n=4047,75.0 \%$ women $)$ to remember their most impactful experience and to indicate who perpetrated the violence (e.g., parent, sibling, (ex)partner). Also, a distinction was made between direct experiences of violence (i.e., the respondent was victimized) versus indirect experiences of violence (i.e., a member of the respondent's household was victimized). In total, 1 in every 5 respondents indicated to have been victim of some form of violence during the pandemic lockdown (Vandeviver et al. 2020).

For psychological violence (i.e., insulting and intimidating behaviours), we found that, overall, 1 in 4 of respondents had experienced this directly or indirectly during the pandemic lockdown. In total, 793 people (19.6\%) indicated that they had directly experienced psychological violence (Vandeviver et al. 2020). When we examine prevalence rates for men and women separately, we find that approximately 1 in every 5 women (21.0\%) and 1 in every 7 men (14.9\%) experienced psychological violence. In half of these cases (51.4\%), the perpetrator was an (ex)partner of the victim. Additionally, 575 respondents $(14.2 \%)$ indicated that someone they lived with (e.g., children, (ex)partner) experienced psychological violence during the pandemic lockdown. In $34 \%$ of these cases, psychological violence was perpetrated by the respondent themselves.

We defined physical violence as the act of physically hurting another person, for example, by kicking, hitting, or biting them. Overall, $2.5 \%$ of respondents $(n=99,82$ of whom were women) indicated they were victim of physical violence during the pandemic lockdown (Vandeviver et al. 2020). In most of these cases, physical violence was perpetrated by an (ex)partner ( $45.2 \%$ of cases) or by the respondent's (step)child (29.8\% of cases). Additionally, $2.9 \%$ of people indicated that someone in their household experienced physical violence. Particularly, respondents most often reported that (step)children were victimized ( $60 \%$ of cases), and that indirect physical violence was most often perpetrated by the 
respondent themselves (31\% of cases), (another) child in the household (29\% of cases), or by an (ex)partner of the respondent (19\%).

Lastly, we examined people's (in)direct experiences with sexual violence during the pandemic lockdown. Specifically, we assessed non-physical sexual violence (e.g., forcing someone to show their intimate body parts in an offline or online setting), sexual violence with physical contact (e.g., unwanted kissing or unwanted stroking intimate body parts), and rape (i.e., (trying to) have sex with someone against their will). We found that 98 respondents (2.4\%) experienced sexual violence during the pandemic lockdown (Keygnaert et al. 2021). In $72 \%$ of these cases, sexual violence was perpetrated by an (ex)partner. For indirect experiences of sexual violence, we found that $0.7 \%$ of respondents reported victimization of someone in their household. Specifically, (ex)partners (50\% of cases) and (step)children (23\%) were mentioned as victims of sexual violence most often. In more than half of these indirect cases $(53.9 \%)$, sexual violence was perpetrated by someone outside of the household.

Help-seeking and reporting

Not only did we examine people's domestic violence experiences during the pandemic lockdown in Belgium in study 2, we additionally asked victims about their help seeking behaviours. Most victims of domestic violence informed someone within their own personal network about their experience (Vandeviver et al. 2020). For psychological and physical violence, 1 in 3 victims did not inform anyone from their personal environment about their experience. For sexual violence, 1 in 2 victims (48.8\%) kept their experience quiet from people in their personal environment. With regard to seeking professional care, we found that $22.8 \%$ of victims reported their experience to professional (online, by phone, or face-to-face) services aimed at helping victims of violence, and that only $4.4 \%$ of all victims reported their experience to the police. Of all types of violence, victims of physical violence most often sought professional care from services $(38.8 \%)$ and police $(10.6 \%)$. When asked about their reasons not to seek help for their victimization experiences, most victims (over 80\%) indicated they felt their experience was not serious enough or they did not contact authorities to protect themselves. Whereas COVID-19 related containment measures were only mentioned by $2.5 \%$ of victims as a reason not to report their experience to the police, the willingness to report to the police was strikingly limited.

In the national safety monitor in 2018 (Federal Police 2018), much higher percentages of people (up to approximately $50 \%$ ) indicated that they were willing to report their victimization experience. It is possible that the COVID-19 pandemic and lockdown measures may have created more indirect rather than direct barriers to seek help, which are not explicitly reflected by the measures of our study. For example, many victims indicated that they did not report their experiences because of fear of retaliation by the perpetrator. As lockdown measures have isolated perpetrators and victims together, fear of retaliation as a reason not to report may have (strongly) increased compared to before the lockdown.

\section{CONCLUSION}

Overall, lockdown measures due to the COVID-19 pandemic had a tangible, but differential impact on crime levels in Belgium. Rates of many crime types in the physical environment dramatically decreased shortly after lockdown measures were instated in March 2020. Conversely, cybercrime rates made a giant leap during the lockdown, possibly due to the displacement of crime from physical to online settings, and due to people's increased vulnerability to fall victim to (pandemic-related) phishing attacks. With regard to drug-related offenses, we observed mixed effects and saw synthetic drug production decreasing while marihuana production increased considerably. Also, over a hundred thousand violations of governmental measures against the COVID-19 pandemic were reported in the first nine months of 2020 in Belgium. 
There are several likely explanations for these changes in crime rates. As the lockdown measures have drastically affected people's daily lives and their routine activities by confining them to their own homes, this also affected people's vulnerability to become victim of a crime. As people spend much less time in public spaces during the pandemic lockdown, physical crimes such as theft and assault occurred much less often in 2020. Consequently, as offenders of physical crimes had less opportunities to conduct such criminal activities, it is possible that some offenders displaced their activities to the online setting, for example by taking part in phishing practices. Considering the fact that people spend much more time online during the pandemic lockdown compared to before (Vandendriessche et al. 2021), increasing their vulnerability of becoming victims of cybercrime, it is perhaps unsurprising that cybercrime was thriving during the pandemic lockdown. Furthermore, it should be considered that not only the routines of criminals and potential victims have changed due to the COVID-19 pandemic, but also those of Belgian law enforcement. The large amount of registered violations of COVID-19 measures reflects that police officers have spent a considerable amount of their time and effort focusing on such offenses, decreasing their capacity to focus on other types of crime (Vantomme 2020). This may for a small part further explain the general decrease in crime rates in Belgium.

When we examine the impact of the COVID-19 pandemic and the lockdown measures specifically for domestic violence, we find that federal police statistics only reveal a limited part of the picture. Rather, victim helplines and survey data indicate much higher prevalence rates of domestic violence during the pandemic lockdown in Belgium. Particularly, the prevalence rates of domestic violence found in our own survey studies are remarkably high. Previous survey research among a representative sample in Belgium found that approximately $50 \%$ of the adult population had experienced psychological (including verbal), physical, and/or sexual violence throughout their lifetime (Pieters et al. 2010). For sexual violence, we found in a recent study among a representative sample of Belgian adults' lifetime prevalence rates of approximately 65\% (Schapansky et al. 2021). Given the relatively short time period in which data were collected during the first month of the pandemic lockdown, the presented prevalence rates for the various types of domestic violence can be considered relatively high. People who were victim of domestic violence might have felt more inclined to take part in our surveys, resulting in an overrepresentation of victims within our samples. However, for reasons mentioned above, such as the increase in calls to victim support services, it can be assumed that domestic violence increased during the pandemic lockdown. As both surveys were primarily distributed through online channels, other groups of people are underrepresented in our samples, such as people without access to online information due to lower financial resources.

Despite several study limitations, the findings of the presented studies in addition to reports from Helpline 1712 illustrate the impact of the COVID-19 pandemic and governmental lockdown measures on domestic violence in Belgium in 2020. Fortunately, in response to this, new initiatives for domestic violence prevention and intervention efforts also followed shortly after lockdown measures were instated. For example, in Belgium and several other countries across the world, the codeword "Mask19" was instated (Verberckmoes 2020). By mentioning this codeword when placing an order at the pharmacy, victims of domestic violence could discretely signal their need for help. Alerted pharmacists would then alert the appropriate authorities so that help could be provided. Other initiatives such as the implementation of a low-threshold and discreet online chatline for victims of sexual violence (Chat na seksueel geweld 2020) and the creation of campaigns aimed at raising domestic violence awareness and increasing visibility of services that provide help during the pandemic (Hulplijn 1712 2020) show that not only crime, but also (societal) responses to crime quickly adapted to the context of the COVID-19 pandemic in Belgium. 


\section{REFERENCES}

Ashby, MP 2020, 'Initial evidence on the relationship between the coronavirus pandemic and crime in the United States', Crime Science, 9, pp. 1-16.

Berete, F, Braekman, E, Charafeddine, R, Demarest, S, Drieskens, S, Gisle, L \& Hermans, L 2020, 'Vijfde COVID-19-Gezondheidsenquête. Eerste resultaten' [Fifth COVID-19 Health survey: first results], sciensano.be. https://www.sciensano.be/en/biblio/vijfde-covid-19gezondheidsenquete-eerste-resultaten. Accessed 20 May 2021.

Boxall, H, Morgan, A \& Brown, R 2020, 'The prevalence of domestic violence among women during the COVID-19 pandemic', Australasian Policing, 12(3), pp. 38-46.

Braekman, E, Charafeddine, R, Demarest, S, Drieskens, S, Gisle, L, Hermans, L \& Van der Heyden, J 2020, 'Vierde COVID-19-Gezondheidsenquête. Eerste resultaten' [Fourth COVID19 Health survey: first results], sciensano.be. https://www.sciensano.be/en/biblio/vierde-covid19-gezondheidsenquete-eerste-resultaten. Accessed 20 May 2021.

Brooks, SK, Webster, RK, Smith, LE, Woodland, L, Wessely, S, Greenberg, N \& Rubin, GJ 2020, 'The psychological impact of quarantine and how to reduce it: rapid review of the evidence', The Lancet, 395(10227), pp. 912-920.

Buil-Gil, D, Miró-Llinares, F, Moneva, A, Kemp, S \& Díaz-Castaño, N 2021. 'Cybercrime and shifts in opportunities during COVID-19: a preliminary analysis in the UK', European Societies, 23(sup1), pp. S47-S59.

Cannon, CE, Ferreira, R, Buttell, F \& First, J 2021, 'COVID-19, Intimate partner violence, and communication ecologies'. American Behavioral Scientist, 65(7), pp. 992-1013.

Casero-Ripollés, A 2020, 'Impact of Covid-19 on the media system. Communicative and democratic consequences of news consumption during the outbreak', El Profesional de la Información, v. 29, n. 2, e290223. https://doi.org/10.3145/epi.2020.mar.23

Cauberghe, V, Van Wesenbeeck, I, De Jans, S, Hudders, L \& Ponnet, K 2021, 'How adolescents use social media to cope with feelings of loneliness and anxiety during COVID-19 lockdown', Cyberpsychology, Behavior, and Social Networking, 24(4), pp. 250-257. DOI: 10.1089/cyber.2020.0478

Chat na seksueel geweld 2020, 'Chat na seksueel geweld' [Chat after sexual violence], Available at: https://www.seksueelgeweld.be/. Accessed 01 Jun. 2021.

Demarest, S, Braekman, E, Charafeddine, R, Drieskens, S, Gisle, L, Hermans, L \& Scohy, A 2020a, 'Eerste COVID-19-Gezondheidsenquête: eerste resultaten' [First COVID-19 Health survey: first results], sciensano.be. https://www.sciensano.be/en/biblio/eerste-covid-19gezondheidsenquete-eerste-resultaten. Accessed 20 May 2021.

Demarest, S, Braekman, E, Charafeddine, R, Drieskens, S, Gisle, L, Hermans, L \& Vandevijvere, S 2020b, 'Derde COVID-19-Gezondheidsenquête: eerste resultaten' [Third COVID-19 Health survey: first results], sciensano.be. https://www.sciensano.be/en/biblio/derde-covid-19-gezondheidsenquete-eerste-resultaten.

Accessed 20 May 2021.

D’hoore, J 2020, 'Zo wil België Italiaanse toestanden vermijden' [This is how Belgium plans to avoid the Italian situation], De Tijd, 10 March. https://www.tijd.be/politiekeconomie/belgie/algemeen/zo-wil-belgie-italiaanse-toestanden-vermijden/10213538.html.

Accessed 05 May 2021. 
Drieskens, S, Braekman, E, Charafeddine, R, Demarest, S, Gisle, L \& Hermans, L 2020, 'Tweede COVID-19-Gezondheidsenquête: eerste resultaten' [Second COVID-19 Health survey: First results], sciensano.be. https://www.sciensano.be/en/biblio/tweede-covid-19gezondheidsenquete-eerste-resultaten. Accessed 20 May 2021.

Eisner, M \& Nivette, A 2020. Violence and the pandemic: Urgent questions for research. New York: Harry Frank Guggenheim Foundation.

Evans, ML, Lindauer, M, \& Farrell, ME 2020, 'A pandemic within a pandemic-Intimate partner violence during Covid-19', New England journal of medicine, 383(24), pp. 2302-2304.

Federal Police Belgium 2020, 'Criminaliteitsstatistieken' [Crime statistics]. http://www.stat.policefederale.be/index-nl.html. Accessed 15 May 2021.

Gillespie, SM, Jones, A, Uzieblo, K, Garofalo, C \& Robinson, E 2021, 'Coping using sex during the coronavirus disease 2019 (COVID-19) outbreak in the United Kingdom', The Journal of Sexual Medicine, 18(1), pp. 50-62

Gracia, E 2004, 'Unreported cases of domestic violence against women: towards an epidemiology of social silence, tolerance, and inhibition.' Journal of Epidemiology \& Community Health, 58, pp. 536-537.

Grommen, S 2020, 'Wat is dat toch met die verwarrende communicatie over de coronaregels? "Debatfiches kunnen hier wel van nut zijn." [What is it with the confusing communication about the corona rules? "Debatfiches might be useful here"], vrtnws.be, 28 July. https://www.vrt.be/vrtnws/nl/2020/07/28/wat-is-dat-toch-met-die-verwarrende-communicatieover-de-coronar/. Accessed 1 Jun. 2021.

Hardyns, W, Keygnaert, I, Ponnet, K \& Vandeviver, C 2020, 'Partner and domestic violence during the COVID-19 crisis', Freedom from Fear, 2020(16), pp. 48-55.

HLN 2020a, 'Criminaliteit zakt met zo'n 30 procent door corona.' [Crime rates drop approximately 30 percent because of corona], Het Nieuwsblad, 24 March. https://www.nieuwsblad.be/cnt/dmf20200324_04900196. Accessed 1 Jun. 2021.

HLN 2020b, '4.000 mensen manifesteren in Brussel voor betere financiering gezondheidszorg.' [4.000 people manifest in Brussels for better financing of health care], vrtnws.be, 13 September. https://www.vrt.be/vrtnws/nl/2020/09/13/betoging-gezondheidszorg/. Accessed 1 Jun. 2021.

HLN 2021, 'OVERZICHT. Van de lockdown op 18 maart tot de recentste coronamaatregelen: dit is het parcours dat België tot nu heeft doorlopen' [OVERVIEW. From the lockdown on March $18^{\text {th }}$ to the most recent coronameasures: this is the course that Belgium has followed so far], Het Laatste Nieuws (HLN), 26 April. https://www.hln.be/binnenland/overzicht-van-delockdown-op-18-maart-tot-de-recentste-coronamaatregelen-dit-is-het-parcours-dat-belgie-totnu-heeft-doorlopen af470e8f/. Accessed 05 May 2021.

Hulplijn 1712 2020, 'PERSBERICHT: "Bang om in uw kot te blijven?” nieuwe campagne over huiselijk geweld' [PRESS RELEASE: “Afraid to stay at home?" new campaign about domestic violence]. $\quad$ https://1712.be/campagnes/id/900/persbericht-bang-om-in-uw-kot-te-blijvennieuwe-campagne-over-huiselijk-geweld. Accessed 1 Jun. 2021.

www.info-coronavirus.be. (2020). Laatste nieuws | Coronavirus COVID-19 [The latest news | Coronavirus COIVD-19]. https://www.info-coronavirus.be/nl/news/. Accessed 05 May 2021.

Keygnaert, I, Fomenko, L, De Schrijver, L, Nobels, A \& Vandeviver, C 2021, 'Eerste bevindingen omtrent Seksueel Geweld en COVID-19 in 2020 in België: Kan een 
voorspellingsmodel helpen in vergelijkbare lockdown-situaties?', Tijdschrift voor Seksuologie, 45(1).

Keygnaert, I, Nobels, A, Schapansky, E, Robert, E, Depraetere, J, De Schrijver, L, De Moor, S \& Vandeviver, C 2020, 'Relaties, Stress en Agressie in tijden van corona in België: Voornaamste bevindingen over de eerste vier weken van de coronamaatregelen - Rapport 1:13 mei 2020', Universiteit Gent.

Lastdrager, EE 2014, 'Achieving a consensual definition of phishing based on a systematic review of the literature', Crime Science, 3(1), pp. 1-10.

Lyons, M \& Brewer, G 2021, 'Experiences of intimate partner violence during lockdown and the COVID-19 pandemic', Journal of Family Violence, 1-9.

De Morgen 2020, 'Cultuursector houdt 'Stil protest' op Belgische pleinen' [Cultural sector organizes 'silent protest' on Belgian squares], De Morgen, 25 June. https://www.demorgen.be/nieuws/cultuursector-houdt-stil-protest-op-belgischepleinen b299408f/. Accessed 1 Jun. 2021.

Nieuwsblad 2020, 'Criminaliteit zakt met zo'n 30 procent door corona' [Crime rates drop about 30 percent due to corona], Nieuwsblad, 24 March. https://www.nieuwsblad.be/cnt/dmf20200324_04900196. Accessed 23 Jun. 2021.

Pieters, J, Italiano, P, Offermans, AM \& Hellemans, S 2010, 'Ervaringen van vrouwen en mannen met psychologisch, fysiek en seksueel geweld' [Experiences of women and men with psychological, physical, and sexual violence], Instituut voor de Gelijkheid van Vrouwen en Mannen.

Piquero, AR, Jennings, WG, Jemison, E, Kaukinen, C \& Knaul, FM 2021, 'Domestic violence during the COVID-19 pandemic-Evidence from a systematic review and meta-analysis', Journal of criminal justice, 74(C).

Ponnet, K, Hardyns, W, Anrijs, S \& Schokkenbroek, J 2020, 'Welzijn en relaties in tijden van corona: Bevindingen van een survey-onderzoek in België van 3-17 april 2020' [Well-being and relationship in times of corona: Findings from a survey study in Belgium from 3-17 April, 2020], Ghent University.

Ritchie, H, Ortiz-Ospina, E, Beltekian, D, Mathieu, E, Hasell, J, Macdonald, B, Giattino, C, Appel, C, Rodés-Guirao, L \& Roser, M 2020, 'Coronavirus Pandemic (COVID-19).' Our World in Data. https://ourworldindata.org/coronavirus/country/belgium?country= BEL. Accessed 06 May 2021.

Schokkenbroek, JM, Ponnet, K, Anrijs, S \& Hardyns, W 2020, 'Determinanten van partnergeweld tijdens de corona lockdown: resultaten van een online vragenlijstonderzoek in Vlaanderen.', Panopticon, 41(4), pp. 408-416.

Schokkenbroek, JM, Anrijs, S, Ponnet, K \& Hardyns, W 2021, 'Locked down together: Determinants of verbal partner violence during the COVID-19 pandemic.', Violence and Gender.

Sciensano 2021, 'Het gebruik en het aanbod van drugs tijdens de COVID-19-pandemie in België. Thematisch rapport: Resultaten van de online enquête Drugs \& COVID-19 in 2020', Sciensano: Brussel, België; depotnummer: D/2021/14.440/21 
Vandendriessche, K, Steenberghs, E, Matheve, A, Georges, A \& De Marez, L 2021, 'Imec Digimeter 2020.', https://drupal.imec.be/sites/default/files/inline-files/DIGIMETER2020.pdf. Accessed 23 Jun 2021.

Vandeviver, C, Depraetere, J, Schapansky, E, De Schrijver, L, Nobels, A, De Moor, S \& Keygnaert, I 2020, 'Slachtofferschap van geweld tijdens de COVID-19-lockdown in België: Eerste resultaten van een lopend nationaal cohorteonderzoek.', Panopticon, 41(4), pp. 417-425.

Van Hoorenbeek, J \& Verberckmoes, Y 2020, 'Corona doet digitale criminaliteit pieken: "Ze weten welke thema's ons interesseren"" [Corona leads to spikes in digital crime: "They know which topics interest us"], De Morgen, 17 December. https://www.demorgen.be/nieuws/corona-doet-digitale-criminaliteit-pieken-ze-weten-welkethema-s-ons-interesseren b49e30db/. Accessed 01 Jun. 2021.

Vantomme, E 2020, 'Coronacrisis heeft impact op politiewerk: "Gezondheid is nu belangrijker dan flitsen"" [Coronacrisis impacts police work: "Public health is more important now than traffic violations"], Nieuwsblad, $17 \quad$ March. https://www.nieuwsblad.be/cnt/dmf20200317_04892828. Accessed 23 Jun 2021.

Verberckmoes, Y 2020, 'Huiselijk geweld detecteren via codewoord: krijgt ook België zijn 'Masker 19'?' [Detecting domestic violence via codeword: will Belgium also get 'Mask 19'?], De Morgen, 9 April. https://www.demorgen.be/nieuws/huiselijk-geweld-detecteren-viacodewoord-krijgt-ook-belgie-zijn-masker-19 b775d4ee/. Accessed 01 Jun. 2021.

Verplancke, J \& Keygnaert, I 2020, 'Chat na Seksueel Geweld tijdens COVID19-maatregelen. Voortgangsrapport 1 april 2020 ten behoeve van Minister Muylle', Universiteit Gent, ICRH 